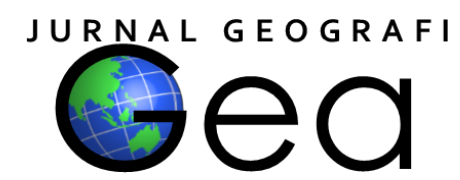

\title{
THE IMPLEMENTATION OF TEACHER STRATEGIES IN MAINTAINING SUNDANESE CULTURE IN THE SENIOR HIGH SCHOOL REGION I WEST JAVA
}

\author{
Yola Puspitasari ${ }^{1}$, Muhammad Zid ${ }^{2}$, Ode Sofyan Hardi ${ }^{3}$ \\ ${ }^{123}$ Geography Education, Faculty Of Social Science, Universitas Negeri Jakarta, \\ 1'yolapuspitasari05@gmail.com, ${ }^{2}$ mzid@unj.ac.id , ${ }^{3}$ ode-sofyan-hardi@unj.ac.id
}

\begin{abstract}
This research aims to analyze the implementation of teacher strategies in maintaining Sundanese Culture in West Java, at Senior High Schools in Region I West Java. The research method used was descriptive-qualitative with literature study. Data collection techniques were done through interviews, documentation, and examining secondary data as complementary data. The results showed that territory that were further away from the Priangan/Bandung area such as Depok City, and parts of Bogor Regency which bordered by Banten and Depok, has cultural acculturation and it was difficult to maintain Sundanese language, so that this region places great emphasis on Sundanese arts and traditional clothes. To instill a love "nyaah" or love of Sundanese culture, namely by implementing Sundanese art activity program strategies and competitions on Sundanese culture in schools by adjusting the language used in the area, namely Indonesian with the Betawinese dialect. Meanwhile for territory of closer Priangan/Bandung like the Sukabumi City, Bogor City, Cianjur Regency, Sukabumi Regency, and parts of Bogor Regency which border Cianjur-Sukabumi, there is no difficulty that the maintenance of Sundanese culture, because the majority of students in this region is the original Sundanese people. Yet these areas implement strategy in the use of language in accordance undak-usuk or origin of Sundanese language through a lesson and outside of a lesson, and focused on aspects art and Sundanese traditional clothes, with an implement strategy through activity program pasanggiri kasundaan (competition on Sundanese) and art Sundanese at school.
\end{abstract}

Keywords: Sundanese Culture, Strategy Implementation, School.

\section{INTRODUCTION}

Indonesia is a country that has cultural diversity in it. According to (sudiadi, 2009), the diversity of cultures, ethnicities, and differences in indonesia is characterized by the presence of thousands of islands. As for the diversity of tribes and cultures, starting with the javanese, sundanese, betawinese, madurese, bataknese, and many more.

Sundanese culture according (ekadjati, 2009), "is a culture that generally resides in west java. The area is also often referred to as tanah pasundan or tatar sunda". In general, the sundanese are reflected in everyday life through language, attitudes and arts. Sundanese people are known to love art and have a friendly, affectionate and emotional personality (koentjaraningrat, 2015).

However, in modern times, sundanese culture and the use of sundanese language are beginning to be unrecognized in sundanese life, even among students, especially at the high school level. This is reinforced by opinion, (rosidi, ekadjati, \& alwasilah, 2006), "that the sundanese language is still considered difficult for high school level students to understand, according to him, in this case the role of government is very important. The west java 
provincial government can imitate the central java provincial government's policy of producing high school graduates interested in javanese literature majoring to improve the quality of teaching local content".

The west java division i which includes sukabumi city, bogor city, depok city, cianjur regency, sukabumi regency, and bogor regency has various cultural characteristics of each region. The people living in this area are more diverse in terms of cultural diversity, language, natural environment and geographic area.

According to (rosidi, ekadjati, \& alwasilah, 2006), thought that "the cultural behavior of every human being in an area has a variety of cultures in aesthetics, ethics, and in discipline. This is influenced by high and low quality and quantity of natural resources, so that it affects the formation of unique and typical of region where they are "there are four territorial division in west java province coordinating board according to government development/bakor $\mathrm{pp}$ (pemprov jabar, 2017) that is, the people residing in this area are more diverse in terms of cultural diversity, natural environment and geographic area. So that this region has a higher acculturation mix of various ethnic groups and immigrants.this is a challenge in maintaining the original culture of west java, namely the sundanese culture. (ranjabar, 2006).

Table 1. Territorial division of West Java Province

Territorial division of West Java Province, according to Bakor PP (2008)

Area I Bogor

Bogor Regency, Bogor City, Depok City, Sukabumi Regency, Sukabumi City, Cianjur Regency.

Area II Purwakarta Purwakarta Regency, Subang Regency, Karawang Regency, Bekasi Regency, Bekasi City.

Area III Cirebon Cirebon Regency, Cirebon City, Indramayu Regency, Majalengka Regency, Kuningan Regency

Area IV Priangan Bandung Regency, Bandung City. Cimahi City, Kab. West Bandung, Sumedang Regency, Garut Regency, Tasikmalaya Regency, Tasikmalaya City, Ciamis Regency, Pangandaran Regency, Banjar City.

Source: Pemprov Jabar (2017)

However, the implementation of strategies in preserving Sundanese culture is currently considered very weak, this is also influenced by the placement of inappropriate strategy implementation. So, this research is important to do and researchers formulate the existing problems, namely about "How to Implementation of School Strategies in Maintaining Sundanese Culture in the Senior High School Region I West Java"

\section{RESEARCH METHODS}

The research was conducted in the senior high schools Region I, West Java Province which includes senior high school from the regency/city as the research location. This location was chosen because it has the criteria needed by researchers, namely as a more heterogeneous area in terms of cultural acculturation. The research was carried out in January-September 2020 Research Subject

In this research, the subjects used as data sources were selected using purposive sampling technique. The purposive sampling technique was chosen by the researcher because it requires special consideration to the research subject in order to provide information in accordance with the research objectives.

Including consideration are:

1. Senior High School (SMA) which still applies the values of Sundanese cultural traditions.

2. Education providers include representatives of school principals who 
are selected based on city and district zoning.

3. Providers of education teaching Sundanese Language and Culture
(Teachers of Sundanese language and literature subjects).

4. Chairman of MGMP Sundanese West Java.

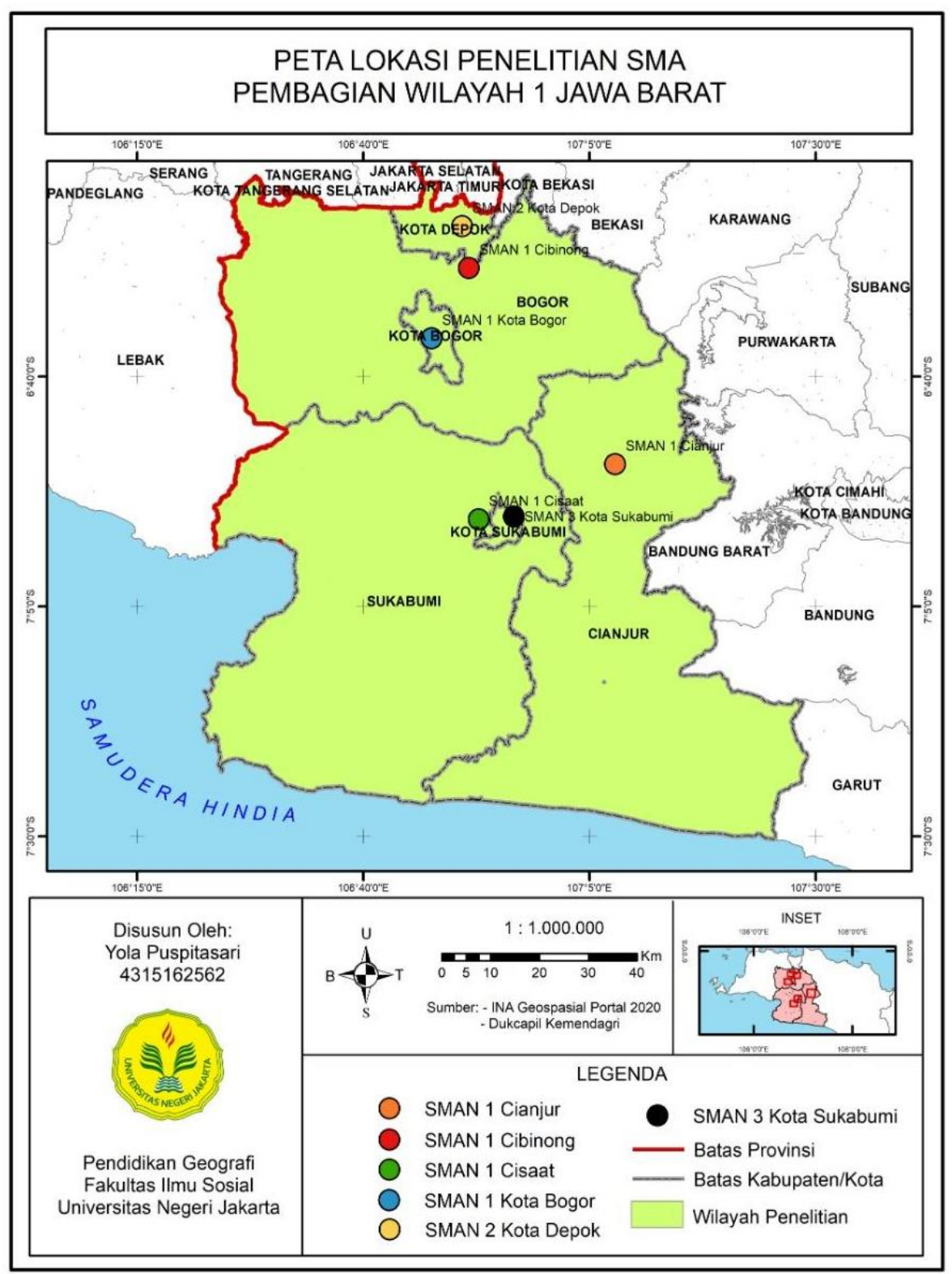

Figure 1. Research Location Map

Table 2. Research Subject

\begin{tabular}{|c|c|c|c|c|}
\hline No & \multicolumn{2}{|c|}{ Key Informants } & Supporting Informants & Amount \\
\hline 1 & $\begin{array}{l}\text { Chairman of MG } \\
\text { West Java }\end{array}$ & Sundanese & & 1 \\
\hline 2 & $\begin{array}{l}\text { Teacher of } \\
\text { Sundanese }\end{array}$ & Language & & 6 \\
\hline 3 & & & School Principal & 2 \\
\hline & & Amount & & 9 \\
\hline
\end{tabular}


This research uses the qualitative descriptive method with literature study. The descriptive method according to Nurazizah \& Darsiharjo, 2018 is to analyze data and phenomena that are happening in an environment. This study uses a qualitative approach, aimed to analyze events from the thoughts of an individual or group, Sukmadinata in (Rosali \& Mainaki, 2019). The data obtained is in the form of an explanation of the information obtained from the informant/resource person regarding the implementation of school strategies in maintaining Sundanese culture in the senior high school division I West Java region. Sources of data obtained in this study consisted of primary data and secondary data.

Primary data obtained included open interviews with open questionnaires which were answered clearly and in writing by informants through the google form platform. This technique is used considering the current condition of the Covid-19 pandemic, and through documentation. Meanwhile, secondary data obtained, among others, through literature studies such as books, research final assignments, articles, scientific documents with sources that can be justified.

The data analysis technique used in this research was carried out through three analysis activities, namely through data reduction, data display/data presentation, and drawing conclusions or verification. This technical analysis is carried out because it is able to provide an overview of school strategies implementation in maintaining Sundanese culture in accordance with the objectives and needs that the researcher wants to get. After all the data has been collected, a source triangulation technique is carried out by comparing all data sources obtained from different sources.The triangulation between researchers is done to test the results of research by trianggulator expert in the Sundanese field, namely by Prof. Dr. Sc. H.M. Ahman Sya, M.Pd., M.Sc..This technique is intended to verify the data already collected by researchers.

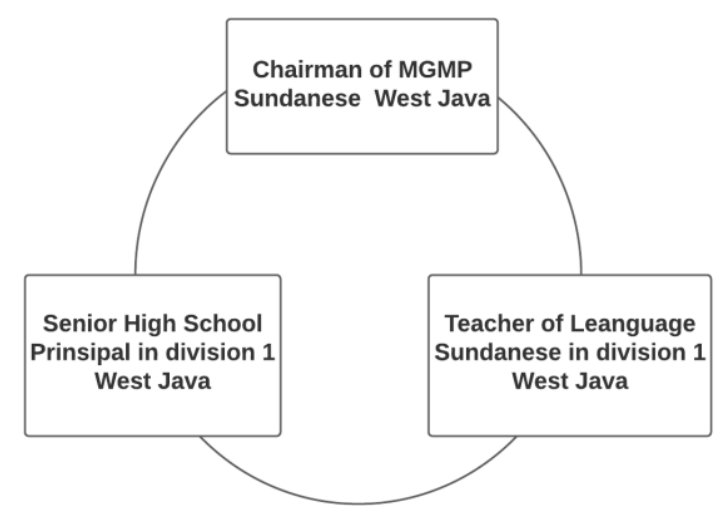

Figure 2. Triangulation Of Research Subject

\section{FINDINGS AND DISCUSSION}

\section{Implementation of School Strategies in} West Java Division I Senior High Schools

Based on the research results obtained, there are 3 area classifications that still apply Sundanese culture along with the implementation of their strategies, in the division I region of West Java Province, which are viewed based on the location of the region.

1. Green Zone.

Areas included in this zone include Cianjur Regency, Sukabumi City and Sukabumi Regency which borders Cianjur Regency such as (Sukaraja District, Sukalarang District, Kebon Pedes District, Geger Bitung District). These areas are adjacent to the Priangan area (Bandung), Therefore it is grouped in the Sundanese Munlok classification (Dinas Pendidikan Jawa Barat, 2017) categorized as Area A, where the use of the language still based on the Sundanese lulugu/standard Sundanese which is used as the main Sundanese language in West Java Province.

The majority of students in this region still use Sundanese as a means of communication, although for some students they still use slang Sundanese in the school environment in short chats with peers. There is an implementation of the school's strategy in the use of language, namely by teaching gradually in using good and correct Sundanese, when communicating at school, through cultural greeting programs such as "Damang Kasep/Geulis kanyaah Ibu/Bapak?" which means "How are you doing boys/girls?, our dear students". Through the Sundanese month pasanggiri program (Sundanese-themed literacy 
competition) such as poetry writing competitions, poetry reading, and Sundanese songs. However, because the majority of students in this region are native Sundanese, this is not a big problem to overcome, so that the use of Sundanese in this area can still be maintained. Sundanese culture in this region can still be maintained through Sundanese arts and Sundanese traditional clothes. As for the implementation of strategies in maintaining Sundanese Culture in this region by implementing and participating in Sundanese Cultural competition activities.

2. Yellow Zone.

The areas included in this zone include the neighboring Sukabumi Regency (Sukabumi City-Bogor Regency-Banten), Bogor Regency (bordering Cianjur Regency-Sukabumi Regency), and Bogor City. Where the location of these areas are slightly shifted from the Priangan area (Bandung), therefore they are grouped in the Sundanese Munlok classification (Dinas Pendidikan Jawa Barat, 2017), and categorized as Area B, where in the use of the language we still use the Sundanese wewengkon or Sundanese language considered different for the type of Sundanese Loma (Sundanese language which is usually used by people who are considered familiar).

The majority of students in this area still use Sundanese as a means of communication, although for some students they still use Sundanese slang in the school environment in short chats with peers. There is an implementation of school strategies in the use of language, namely by teaching gradually in using Sundanese language properly and correctly, when communicating at school. In addition, it also teaches for nyaah (love) the Sundanese language which is implemented through the tradition of implementing greetings and greetings every morning at school using Sundanese such as "Sampurasun/rampes" which means "excuse me/please" and getting used of communicating with Sundanese language in the school environment.
The use of Sundanese in this area can still be maintained even though the Sundanese dialect is different from the areas in the green zone. Sundanese culture in this region can also be maintained through Sundanese arts and clothing, the implementation of strategies in maintaining Sundanese culture in this region by implementing and participating in Sundanese competition activities, for example jaipong dance competitions, pupuh competitions, etc. As well as introducing Sundanese Culture through Sundanese extracurricular activities.

\section{Red Zone}

The area included in this zone includes Depok City and parts of Bogor Regency which borders it (Depok City, Bogor City, Bekasi, Banten). The location of these areas is closer to the DKI Jakarta Province, which means that the area has cultural acculturation, which is dominated by the Betawinese Culture. This is in line with previous research by (Zid \& Saifuddin, Relasi Regionalisasi Kebudayaan Dalam Praktik Sosial Masyarakat: Studi Awal terhadap JaringJaring Kebudayaan-Sosial Masyarakat di Wilayah Nodal Jakarta, Bogor, Depok Tangerang, dan Bekasi, 2014) suggested that socio-geographically, the City of Depok and Bogor Regency bordering Jakarta, such as Bekasi and Tangerang, is in line with the theory of the melting pot, where the areas with a very strategic geographical location is a place for interaction between various ethnic groups and cultural identity that affect each other.

Depok and some districts adjacent to Bogor (Depok City, Bekasi and Banten) are administratively part of West Java Province. Therefore, in the Sundanese munlok the area included in this zone includes Depok City and parts of Bogor Regency which borders it (Depok City, Bogor City, Bekasi, Banten). The location of these areas is closer to the DKI Jakarta Province, which means that the area has cultural acculturation, which is dominated by the Betawinese Culture. This is in line with previous research by (Zid \& Saifuddin, Relasi Regionalisasi 
Kebudayaan Dalam Praktik Sosial Masyarakat: Studi Awal terhadap JaringJaring Kebudayaan-Sosial Masyarakat di Wilayah Nodal Jakarta, Bogor, Depok Tangerang, dan Bekasi, 2014) suggested that socio-geographically, the City of Depok and Bogor Regency bordering Jakarta, such as Bekasi and Tangerang, is in line with the theory of the melting pot, where the areas with a very strategic geographical location is a place for interaction between various ethnic groups and cultural identity that affect each other.

Depok and some districts adjacent to Bogor (Depok City, Bekasi and Banten) are administratively part of West Java Province. Therefore, in the Sundanese munlok (Local content) (Dinas Pendidikan Jawa Barat, 2017), this region is categorized as Area C, where the use of the language based on Sundanese wewengkon or informal Sundanese language with the infuence of Indonesian or local dialects (Malay/Betawi).

The majority of students in this region use Indonesian (Malay-Betawi) as a means of communication, but in this area Sundanese is still used by some teachers, school principals, and school officials who can only speak Sundanese.

This is in line with previous research by (Sudarma, Wahya, Citraresmana, Indira, Muhtadin, \& Lyra, 2019), that philosophically, as time passed, science and technology as well as globalization affects the habits and attitudes of society which means experiencing social change. (Soekanto in (Zid, et al., 2017), Sundanese language which is geographically spread in West Java, Banten, and the border of West Java and Central Java Banten faces various problems. The existence of Indonesian as the national language and the state language also influences the life of the Sundanese language, as well as Sundanese culture.

There is an implementation of the school's strategy in using language, namely by holding the Nyunda Day program (a special day for Sundanese Language) which aims to facilitate students' understanding in understanding Sundanese language and culture.

Sundanese language can be used when teaching. Teachers can use Indonesian language with Sundanese prefaces, so that students can adjust with their level of understanding in the region of the school. Another strategy implementation is applying Sundanese Cultural greetings with easily understood sentences, that are easy to remember and understand by students, such as the sentence "wilujeng enjing and wilujeng sonten" which means good morning and good afternoon, "Punten" means "sorry/excuse me", and "Hatur nuhun" which means "Thank you".

Other Sundanese cultures that can still be maintained are Sundanese arts and Sundanese traditional clothes. The application of strategies in

Maintaining Sundanese culture in this region can be done by introducing Sundanese activities in schools through (Local content) (Dinas Pendidikan Jawa Barat, 2017), this region is categorized as Area $\mathrm{C}$, where the use of the language based on Sundanese wewengkon or informal Sundanese language with the infuence of Indonesian or local dialects (Malay/Betawi).

The majority of students in this region use Indonesian (Malay-Betawi) as a means of communication, but in this area Sundanese is still used by some teachers, school principals, and school officials who can only speak Sundanese.

This is in line with previous research by (Sudarma, Wahya, Citraresmana, Indira, Muhtadin, \& Lyra, 2019), that philosophically, as time passed, science and technology as well as globalization affects the habits and attitudes of society which means experiencing social change. (Soekanto in (Zid, et al., 2017), Sundanese language which is geographically spread in West Java, Banten, and the border of West Java and Central Java Banten faces various problems. The existence of Indonesian as the national language and the state language also influences the life 
of the Sundanese language, as well as Sundanese culture.

There is an implementation of the school's strategy in using language, namely by holding the Nyunda Day program (a special day for Sundanese Language) which aims to facilitate students' understanding in understanding Sundanese language and culture.

Sundanese language can be used when teaching. Teachers can use Indonesian language with Sundanese prefaces, so that students can adjust with their level of understanding in the region of the school. Another strategy implementation is applying Sundanese Cultural greetings with easily understood sentences, that are easy to remember and understand by students, such as the sentence "wilujeng enjing and wilujeng sonten" which means good morning and good afternoon, "Punten" means "sorry/excuse me", and "Hatur nuhun" which means "Thank you".

Other Sundanese cultures that can still be maintained are Sundanese arts and Sundanese traditional clothes. The application of strategies in

Maintaining Sundanese culture in this region can be done by introducing Sundanese activities in schools through

\section{CONCLUSIONS}

There are some areas closer to jakarta, such as depok city, some bogor districts bordering banten, bekasi and depok, there will be cultural acculturation, which creates more diversity especially in the language. so that this region places great emphasis on aspects of sundanese culture such as sundanese arts and traditional clothing. as for the implementation of the strategy, namely, habituating daily sundanese culture (smile, greetings, courtesy, and politeness) in sundanese such as sampurasun and rampes (excuse me and please), wilujeng enjing and sonten (good morning and good afternoon), hatur nuhun (thank you), holding and introducing sundanese art activity programs such as sundanese dance, kakawihan (sundanese songs), sundanese literature, and implementing sundanese clothing programs has been recommended by the west java provincial government, which also includes the sundanese pasanggiri (sundanese competition) at schools, which aims to maintain sundanese culture in order to remain exist in the region. Meanwhile for areas near to the priangan/bandung such as sukabumi city, bogor city, cianjur regency, sukabumi regency, and some bogor districts bordering cianjursukabumi, there is no difficulty in maintaining sundanese culture, because the majority of students in this region are native sundanese. this region implements strategies in the use of language through classroom lessons and outdoor lessons, cultural greeting programs, sundanese art activities, and holding pasanggiri (sundanese competitions) in school to maintain the authenticity of sundanese culture.

\section{RECOMMENDATION}

\section{For schools:}

In order to optimize the application of strategy in Depok and Bogor areas that are influenced by acculturation, it is suggested to introduce language and culture Sundanese through utilization of media that depicts the natural environment, social programs, and cultural programs that still enlivening Sundanese culture. It aims primary school students to be able to interact directly with the native Sundanese in West Java, that they know that the use of language and cultural.

\section{For Researchers:}

Further research is suggested to make observations. Observations are made to determine cultural differences in each school in the West Java division I through direct observations in the field, so that the data obtained would be completer and more indepth.

\section{REFERENCES}

Dinas Pendidikan Jawa Barat. 2017. Kurikulum Tingkat Daerah MunLok Mata Pelajaran Bahasa Dan Sastra Sunda Berbasis Kurikulum 2013 Revisi 2017 Jenjang SMA/SMK/MA/MAK. Jawa Barat: Dinas Pendidikan.

Ekadjati, S. Edi. 2009. Kebudayaan Sunda (Suatu Pendekatan Sejarah jilid 1). Jakarta: PT Dunia Pustaka Jaya. 
Koentjaraningrat. 2015. Kebudayaan, Mentalitas, dan Pembangunan. Jakarta: PT. Gramedia Pustaka Utama.

Nurazizah, Ghoitsa Rohmah. Darsiharjo. 2018. Kesiapan Masyarakat Desa Wisata di Kampung Seni \& Budaya Jelekong Kabupaten Bandung. Jurnal Geografi Gea. $103-113$.

Pemprov Jabar, 2017. (Online). Pembagian Wilayah di Jawa Barat. Tersedia di www.jabarprov.go.id diakses 17 Juli 2020, pukul 08.15 WIB).

Ranjabar, Jacobus. 2006. Sistem Sosial Budaya Indonesia. Bogor: Ghalia Indonesia.

Rosali, Satiyasih Ely. Mainaki, Revi. 2019. Nilai-Nilai Kebudayaan Kampung Adat Dukuh Sebagai Bentuk Kearifan Lokal Hidup Selaras Dengan Lingkungan. Jurnal Geografi Gea. 67 - 75.

Rosidi, Ajip. Ekadjati, S Edi. Alwasilah, A Chaedar. 2006. Konferensi Internasional Budaya Sunda (KIBS) Prosiding Jilid 1. Bandung: PT Kiblat Buku Utama. Jakarta: PT Dunia Pustaka Jaya.

Sudarma, Djaja.. Wahya., Citraresmana, Elvi., Indira, Dian., Muhtadin, Teddi., Lyra,
Hera Meganova. 2019. Upaya Pemertahanan Bahasa-Budaya Sunda Di Tengah Pengaruh Globalisasi. Jurnal Pengabdian Masyarakat. 2 (12): 10361038 tersedia di https://jurnal.unpad.ac.id

Sudiadi, Dadang. 2009. Menuju kehidupan Harmonis Dalam Masyarakat Yang Majemuk. Suatu Pandangan Tentang Pentingnya Pendekatan Multikultural Dalam Pendidikan Di Indonesia. Jurnal Kriminologi Indonesia. 5 (1): 33-42.

Zid, M ., Hardi, S. O., Falah, H., Puspa, P., Afnia, N., Sari, L., Endrastanto., Mawah, N., Ramadhaniyah, A. 2017. Interaksi Dan Perubahan Sosial Masyarakat Baduy Di Era Modern. Jurnal Spatial Wahana Komunikasi dan Informasi Geografi. PP: $14-24$.

Zid, M., Saifuddin. 2014. Relasi Regionalisasi Kebudayaan Dalam Praktik Sosial Masyarakat: Studi Awal terhadap Jaring-Jaring Kebudayaan-Sosial Masyarakat di Wilayah Nodal Jakarta, Bogor, Depok Tangerang, dan Bekasi. Sipeg UNJ (www.sipeg.unj.ac.id. PP: 116/Diakses 30 Januari 2021, pukul 15.00 WIB) 